Jurnal Pengabdian kepada Masyarakat

\title{
Innovation of batteries and inverters as energy saving technology without fuel
}

\author{
Andi Sri Irtawaty ${ }^{1}$, Lilik Damayanti ${ }^{2 *}$ Subur Mulyanto $^{3 *}$ \\ ${ }^{1,2,3}$ Politeknik Negeri Balikpapan \\ *andi.sri@poltekba.ac.id
}

\begin{abstract}
Kata Kunci: pembangkit

listrik tanpa

bbm, hemat

energy, bbm,

penerangan,

kelurahan

manggar

Abstrak Energi listrik merupakan kebutuhan primer dalam kehidupan manusia modern. Namun dengan meningkatnya harga bbm, maka diperlukan sebuah teknologi yang tepat untuk mengatasinya, berupa inovasi aki dan inverter yang dikombinasikan menghasilkan output 220 volt ac yang kemampuannya sama dengan listrik PLN. Kegiatan PkM DPRM ini dilaksanakan di Kelurahan Manggar selama 3 hari yaitu tanggal 30 Juli, 3 Agustus dan 4 Agustus 2020 yang dihadiri oleh warga nelayan, pedagang gorengan dan karyawan Kelurahan Manggar itu sendiri. Alat yang dirancang berkapasitas 300 watt dan 1000 watt, disesuaikan dengan kebutuhan warga. Manfaatnya sangat meringankan penggunaan solar genset bagi warga nelayan yang semula $R p$ 108.000/bulan, kini menjadi $R p$ 0,- . Demikian pula bagi pedagang gorengan, yang semula membayar listrik $R p 70.000$ / bulan untuk penerangan di malam hari, kini menjadi $R p$ 0,-. Berdasarkan hasil kuisioner, peserta telah berhasil mengimplementasikan alat tersebut untuk menyalakan 1 titik lampu 10 watt, 1 kipas angina kecil dan 1 charger hp secara bersamaan selama 4 jam. Bahkan jika hanya salah 1 yang dinyalakan, misalkan 1 lampu 10 watt dapat bertahan selama 8 jam menurut penuturan pedagang gorengan. Sumber daya alat tersebut berasal dari aki 12 volt 5 AH untuk kapasitas 300 watt dan aki 12 volt $8 A H$ untuk kapasitas 1000 watt dan hanya membutuhkan waktu 2 jam untuk mengecharge aki tersebut jika telah soak.
\end{abstract}

Keywords: power plants without fuel, save energy, fuel, lighting, manggar kelurahan

\begin{abstract}
Electrical energy is a primary need in modern human life. However, with the increase in fuel prices, the right technology is needed to overcome it, in the form of battery and inverter innovations which are combined to produce an output of 220 volts ac which has the same capacity as PLN electricity. This PkM DPRM activity was held in Manggar Village for 3 days, namely @ u on July 30, August 3 and August 4, 2020 which was attended by fishermen, fried food traders and Manggar Village employees themselves. The equipment is designed with a capacity of 300 watts and 1000 watts, tailored to the needs of the residents. The benefit greatly eases the use of diesel generator sets for fishermen, which from Rp. 108,000 / month, has now become Rp. 0, -. Likewise for fried food traders, who originally paid Rp. 70,000 / month for electricity for lighting at night, now it is Rp. 0, -. Based on the results of the questionnaire, the participants have successfully implemented the tool to turn on 110 watt light point, 1 small wind fan and 1 cellphone charger simultaneously for 4 hours. Even if only 1 is turned on, for example 110 watt lamp can last for 8 hours according to the narrative of a fried food trader. The power source for this tool comes from a 12 volt $5 \mathrm{AH}$ battery for a capacity of 300 watts and a 12 volt $8 \mathrm{AH}$ battery for a capacity of 1000 watts and only takes 2 hours to charge the battery when it is worn out.
\end{abstract}




\section{INTRODUCTION}

In this decade, Indonesia has entered the peak era of the energy crisis due to the impact of the increase in world oil prices reaching 75 US dollars / barrel in April 2019 (CNN, 2019). As a result, the price of domestic fuel oil has adjusted quite sharply, it is the price of premium gasoline, which was originally IDR 6,450.00 / liter (in 2018) to IDR 9,500.00 / liter (as of August 30, 2019)

Diesel, which was previously IDR 7,000.00 (in 2018) increased to IDR 8,250.00 / liter (as of August 30, 2019). As of January 5, 2020, in East Kalimantan, the price of pertalite was IDR 7,850.00 / liter , non-subsidized diesel Rp. 9,300.00/liter, and subsidized diesel Rp. 6000.00/liter (CNBC, 2018). Electrical energy is a primary need in modern human life. Almost all aspects of life require electrical energy as the prime mover. In general, the source of human electrical energy apart from PLN is also from generator engines which mostly use fuel oil. The factor of increasing fuel oil and the increasing need for the population to use electricity has resulted in environmental and economic problems, especially for the middle to lower economic community (Juwito, 2012).

Based on this background, it is necessary to have the right solution in overcoming these economic difficulties, so it is necessary to design a power plant without using fuel oil, so that the use of electricity consumption for the lower middle class can be more efficient. One of solution is needed such as wind and solar energy, as was done by previous researchers, namely using the Hybrid Optimization Model For Electric method using wind and solar energy (Arota, 2013).

Other researchers have made a prototype generator steam power that has be tested for student practicum tools so that it canimprove students' knowledge and scientific thinking skills in learning energy conversion (Yani, 2018). In this community enagegement activity, using a 12 volt battery energy source with an additional inverter to convert the DC input source to 220 volt AC output. Several researchers have tested the ability of the inverter to generate alternative energy to replace PLN with the input source from the battery (Hutagulung, 2017) (Sinaga, 2016) (Mundus, 2010) (Wardhana, 2006).

The partners that choosen for this program are society in Kelurahan Manggar, whose works as fishermen and fried food seller. The urgent factors that are become the target of this community service activity $(P k M)$ program include: 1 . Train the society of Kelurahan Manggar in designing a power plant without fuel with a capacity of 1000 watts; 2 . Testing the performance of a 1000 watt power plant without fuel based on the parameters of the output voltage and current strength; 3. Describe the time length of operation of a 1000 watt power plant without fuel; 4. Comparing the advantages of a power plant without fuel with a capacity of 1000 watts with a power plant using fuel with the same capacity, in 1000 watts; 5. Explained that power plants without fuel are more efficient than power plants using fuel in providing lighting for fishing boats and people's homes and for running the electrical equipment for fried food seller such as water machines and refrigerators, in addition to the use of electricity from PLN. Meanwhile, the ultimate goal of this $\mathrm{PkM}$ is to improve the welfare of partners who previously spent electricity usage costs of Rp. 108,000 / month to Rp. 0, - after using the power plant without fuel. This means that with the presence of this tool, the society have saved their electricity payments. 


\section{METHOD}

The method of implementing this community service activity includes the following stages :

\section{First Stage (Preparation)}

This stage includes a survey of locations that are targeted by partners, it is in Kelurahan Manggar, Kecamatan Balikpapan Selatan, Kota Balikpapan. The problems faced by the community in Kelurahan Manggar are the increasing of fuel prices and the level of the community's economy is still classified as middle to lower class, most of them work as fishermen and fried food seller, so the team that proposes PkM activities will provide the right solution to increase the economic level of the community in Kelurahan Manggar, in the form of providing training on how to design a power plant without fuel for the needs of lighting the fishing boats and people's homes as well as for water machines and refrigerators for fried food seller.

\section{Second Stage (Design of a power plant without fuel).}

At this stage, the PkM team of DRPM 2020 has prepared 20 complete component units for partners (20 participants consisting of 11 fishermen, 3 housewives, 4 entrepreneurs and 2 employees in Kelurahan Manggar). Tools with a capacity of 300 watts are 19 units and one with a capacity of 1000 watts is 1 unit. Figure 1 below describes the process of designing a power plant without fuel until the testing stage. 


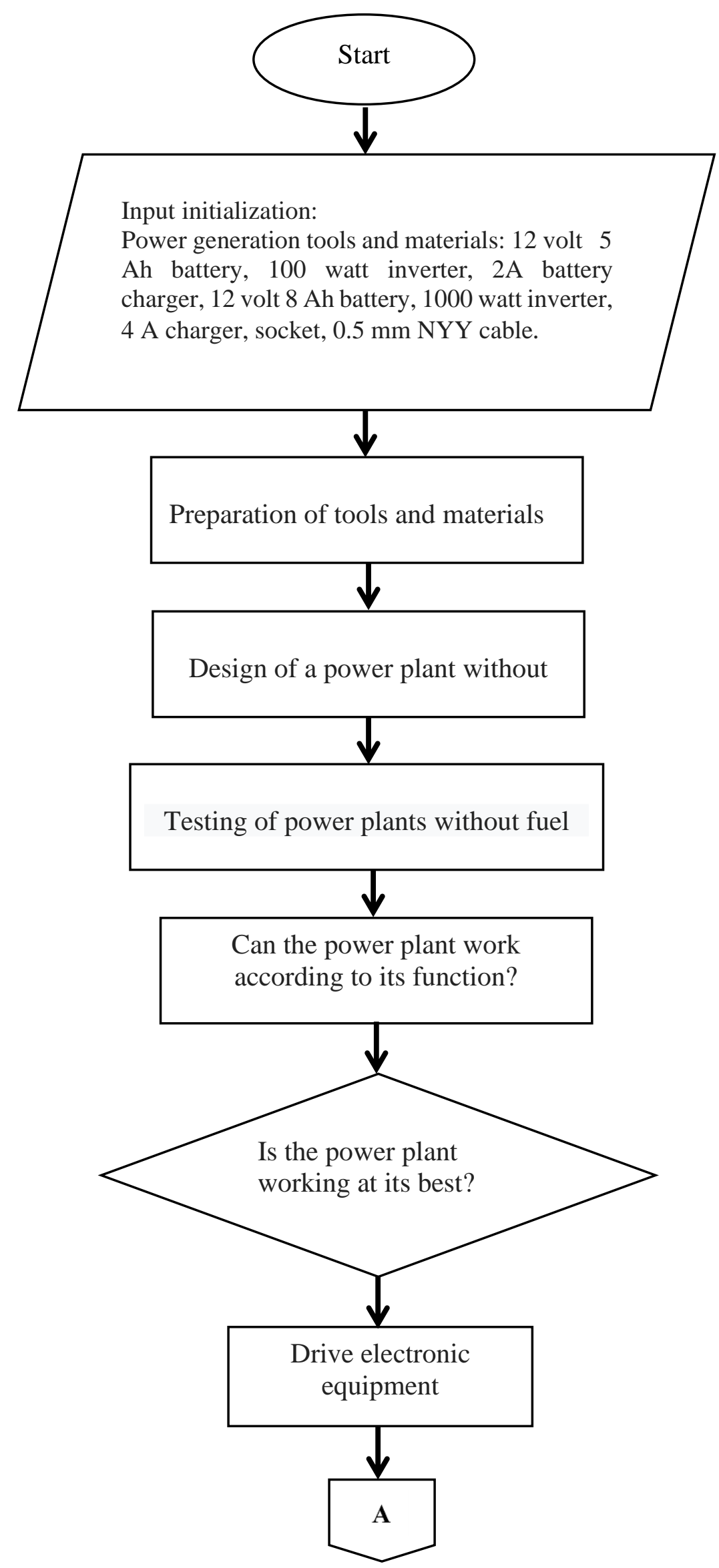




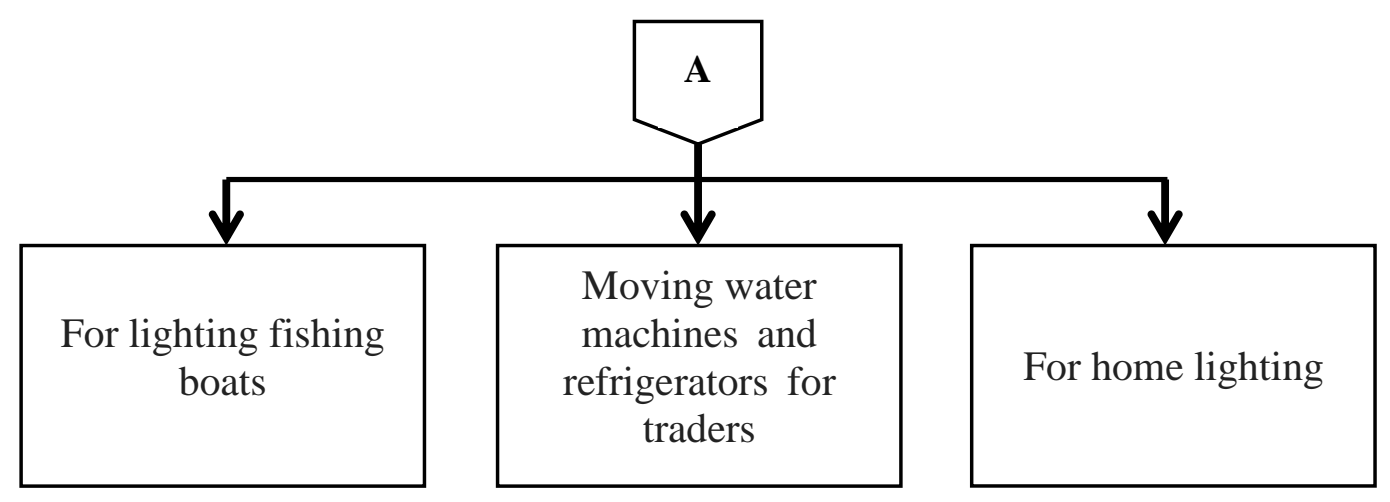

Figure 1. Flowchart of Power Plant Without fuel

The PkM activity on the first day (July 30, 2020), each participant assembled the power plant, guided by the PkM team.

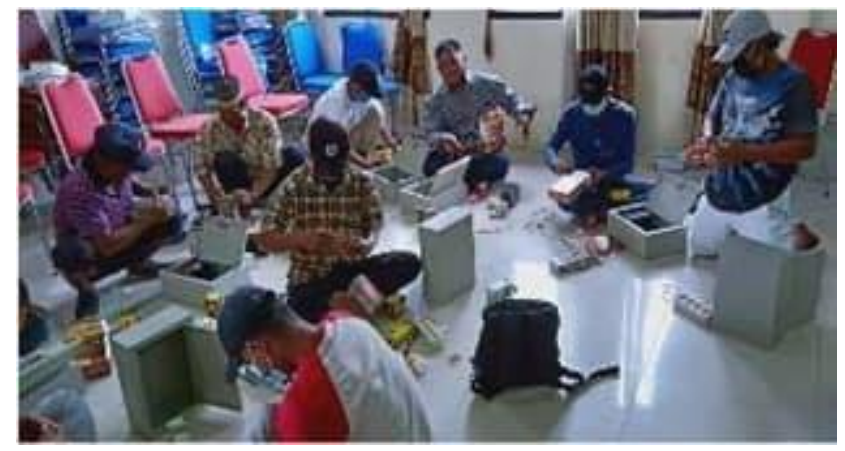

Figure 2. The practice of assembling a power plant

Followed by testing the tools of each participant, as seen in Figure 3.

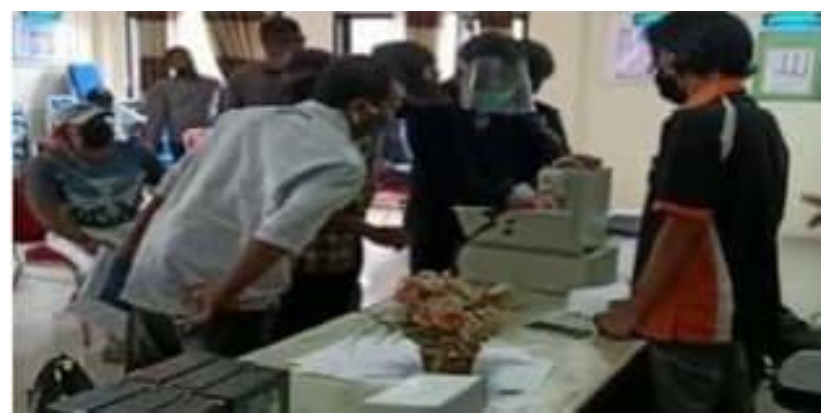

Figure 3. Testing tools designed by each participant.

\section{Third Stage (Testing of Power Plants without fuel)}

On the second day of the PkM activity, it is a symbolic testing phase to support the procession of handing over tools from the PkM DPRM team to partners. 


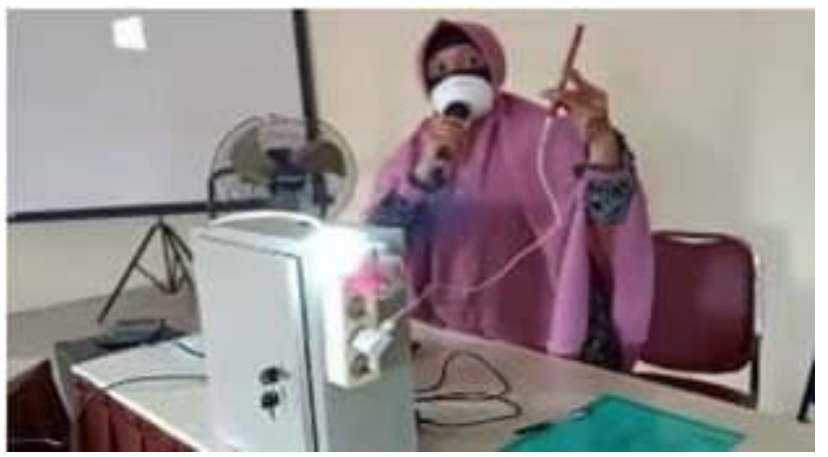

Figure 4. Symbolic testing of tools to support the procession of handing over of tools from the DPRM PkM team to partners.

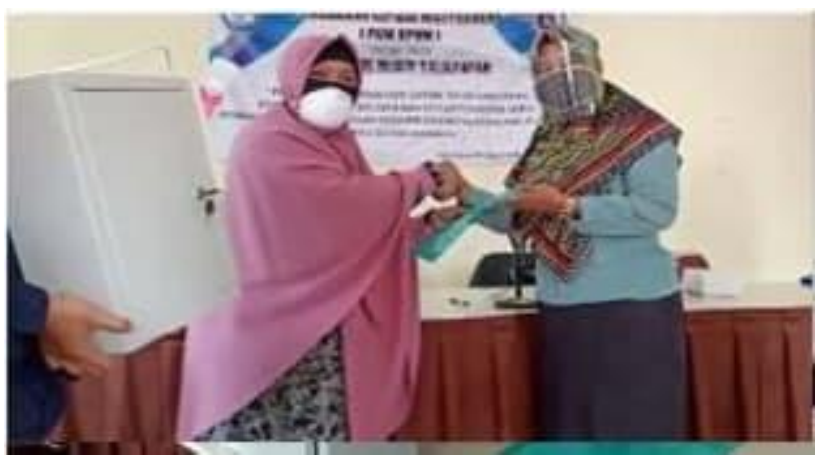

Figure 5. The process of handing over of tools from the head of PkM DRPM team to partners (Kelurahan Manggar).

\section{Fourth Stage (Analysis and Discussion)}

On third day (August 4, 2020), PkM activities were held by online. Each PkM participant and PkM team are provided with an internet quota according to online needs. The core activities in third day are participants were welcome to convey grievances and also suggestions and comments regarding all PkM activities that had been held for 2 days. Gratefully, the participants show high enthusiastic and positive response to this activity. They hope that in the following year, PkM activities will be held in Kelurahan Manggar with other technological innovations that can improve the welfare of fishermen and fried food seller.

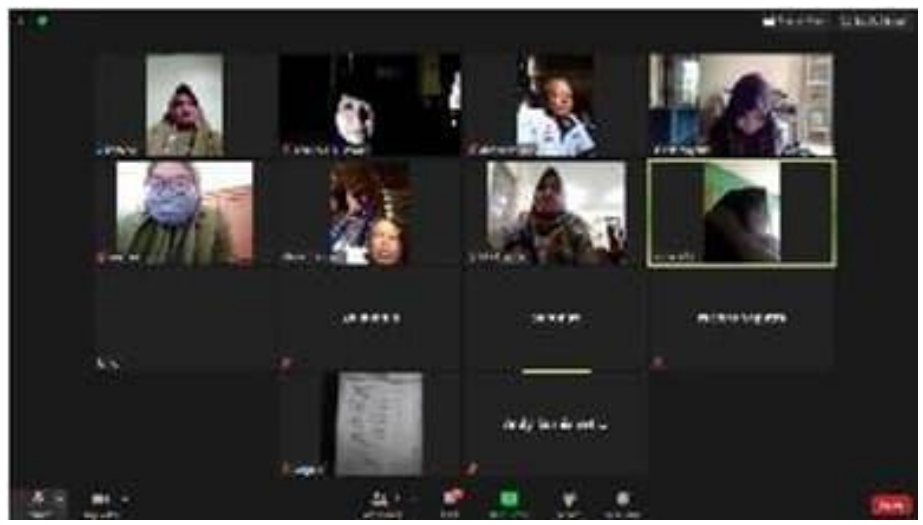

Figure 6. PkM DPRM Activities on the third day (online). 


\section{Fifth Stage (Conclusion)}

The PkM Team has succeeded in sharing the knowledge and technology of the power plant without fuel with partners in Kelurahan Manggar for 3 working days. The result is that fishermen and fried food seller are able to implement the power plant without fuel in their daily life, especially for lighting fishing boats, and other purposes.

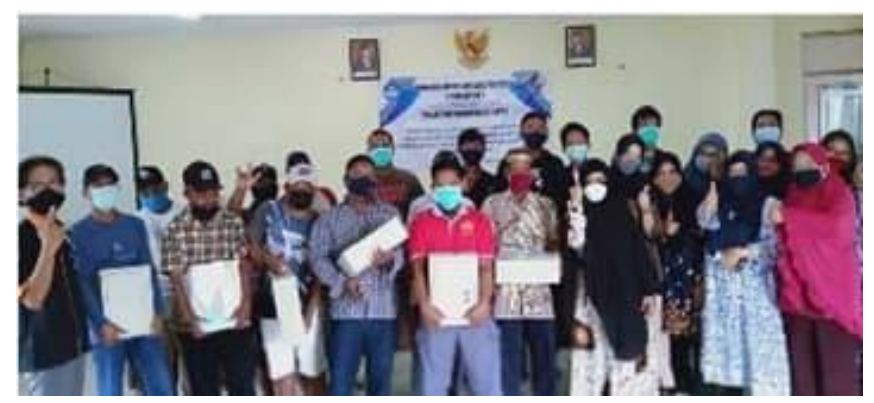

Figure 7. Photograph with the PkM team and partners of Kelurahan Manggar

\section{RESULTS AND DISCUSSION}

The PkM DPRM 2020 activity was held for 3 days, there are July 30, August 3, and August 4, 2020, with 20 participants consist of (11 fishermen, 3 housewives, 4 entrepreneurs, and 2 employees of Kelurahan Manggar). The activity rundown for 3 working days, are bellow.

First Day (July 30, 2020)

The PkM team activities are held offline / face-to-face between the organizers (the team of PkM DRPM 2020) and the partners / hosts (the participants of PkM DRPM 2020). The event began with an opening speech from the head of the PkM DPRM 2020 (Andi Sri Irtawaty, ST, M.Eng.), speech from the Balikpapan State Polytechnic (Subur Mulyanto, ST, MT) and speech from Head of Manggar, represented by the Head of Community Empowerment (Linda Anggraini, S.Kom.). After that, it was continued with the main event, it is the presentation of basic materials, namely alternative energy sources presented by Lilik Damayanti, S.S., M.Hum, and alternative energy sources without fuel by Subur Mulyanto, S.Pd., M.T.

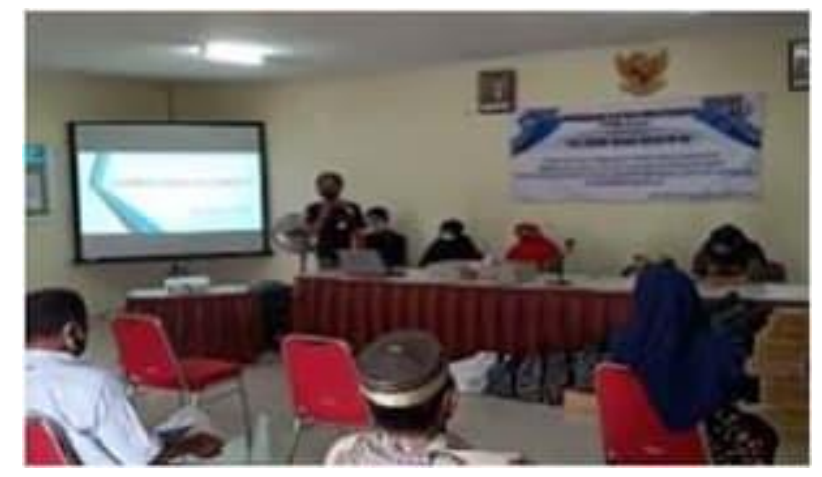

Figure 8. Presentation of the basic material for a power plant without fuel for activities

Furthermore, it is continued with direct practice of designing an alternative energy source device without fuel, the main device is a 12 volt battery 5 amperes, 1000 watt inverter and 2 ampere battery charger. Supported by additional devices, there are 4 point socket, 2 ampere MCB, $0.5 \mathrm{~mm}$ NYY cable. 


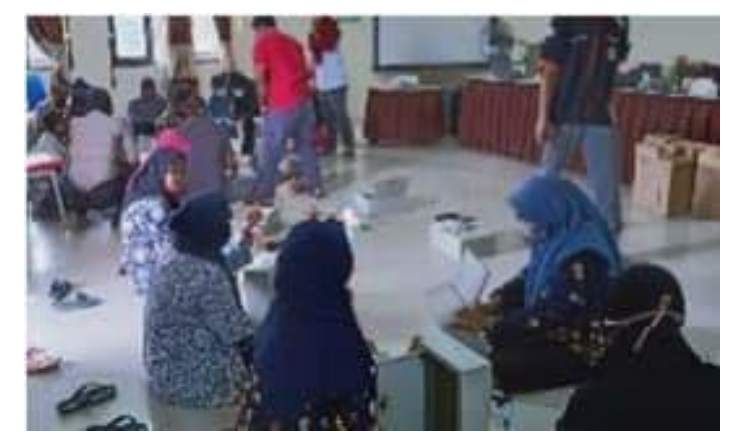

Figure 9. Direct practice of participants in Kelurahan Manggar / partners accompanied by the team of PkM DRPM 2020

At the end of the session, testing the equipment that had been designed was represented by a partner who works as a fisherman.

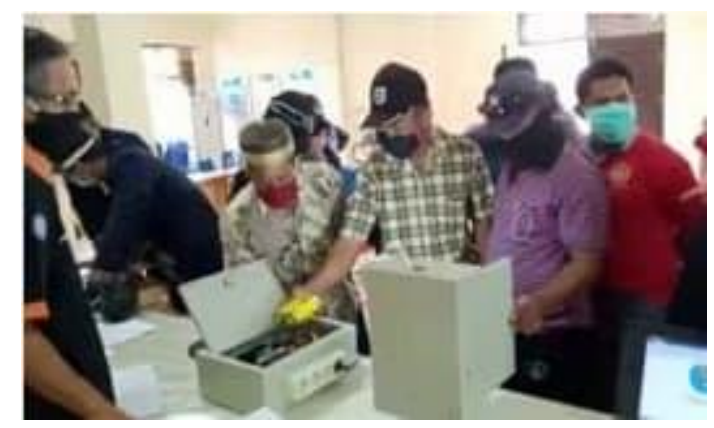

Figure 10. Testing of fuelless power plant tools assembled by fishermen

Continued with the partners' impressions regarding the implementation of PkM DPRM 2020 on the first day, represented by one of the participants who works as a fried food seller.

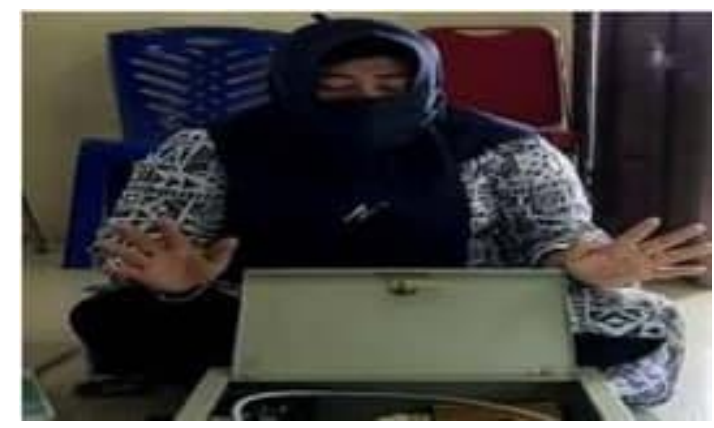

Figure 11. Participants' impressions regarding the results of assembled power plants without fuel.

\section{Second Day ( August 3, 2020 )}

The team of Pkm DRPM 2020 activities on the second day were also carried out offline. The event rundown includes symbolic testing of a power plant without fuel that accompanied by signing the minutes of handover of 20 units (19 units of 300 watts capacity and 1 unit of 1000 watts capacity). 


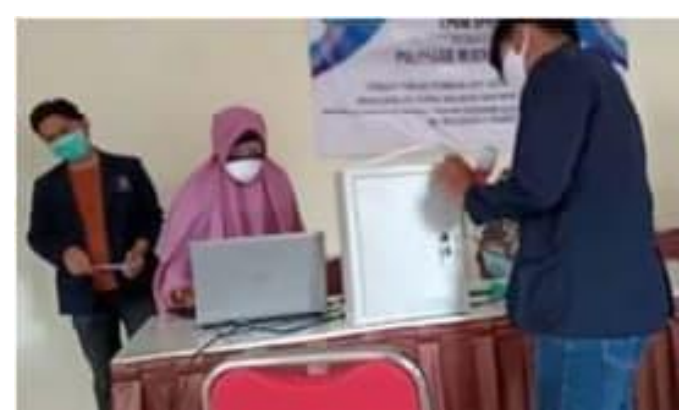

Figure 12. Symbolic testing of a power plant without fuel in front of partners

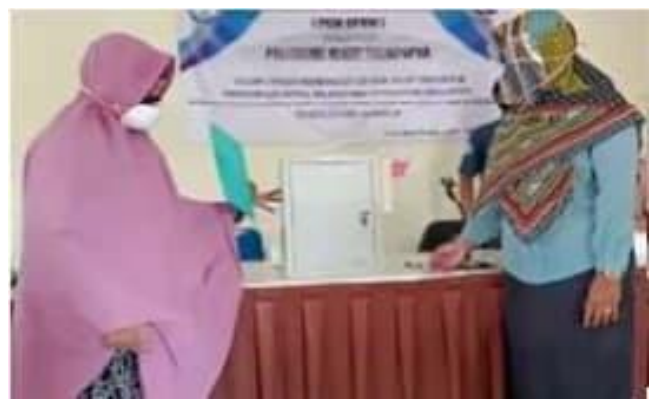

Figure 13. The process of symbolically handing over the tools by signing the official report from both parties (the PkM DPRM 2020 team and Kelurahan Manggar partners)

\section{Third Day (August 4, 2020 )}

The PkM activities on the third day were held by online. The Team has distributed internet quota to each participant. However, due to problems with unsupported cellphones, only 13 participants took part in online meeting on the last day (only Android phones supported the zoom meeting application).

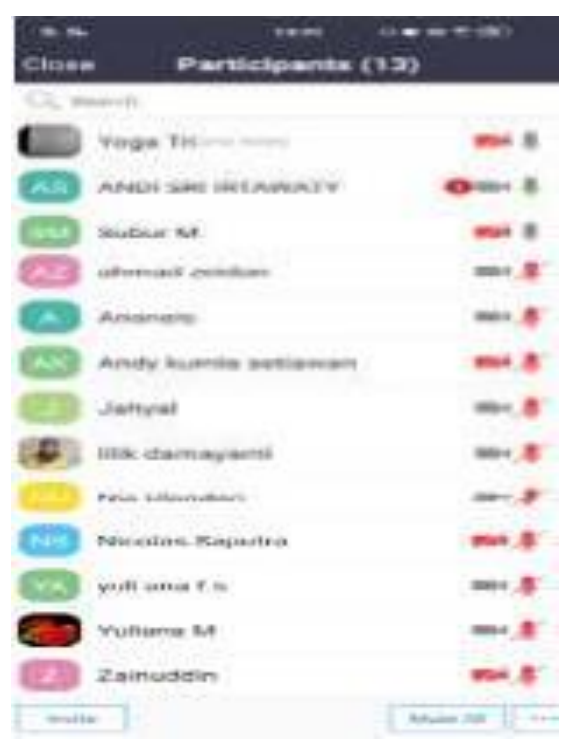

Figure 14. The number of online participants for the PkM DRPM 2020 on the third day 
The rundown of the event began with the presentation of tips for making handsanityzers which was guided by the team leader of PkM DRPM 2020.

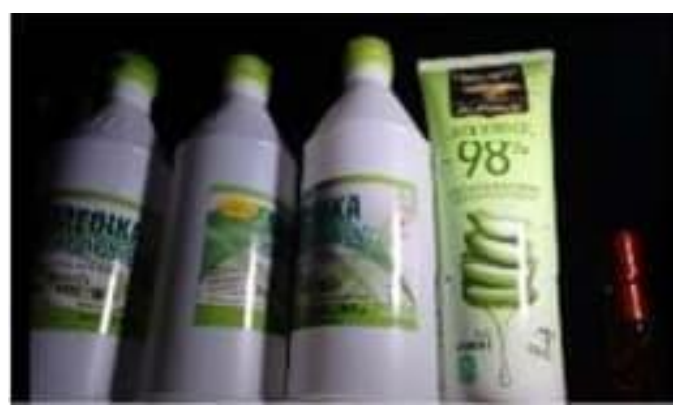

Figure 15. Materials for making hand sanitizers

Followed by question and answer session with partners of Kelurahan Manggar.

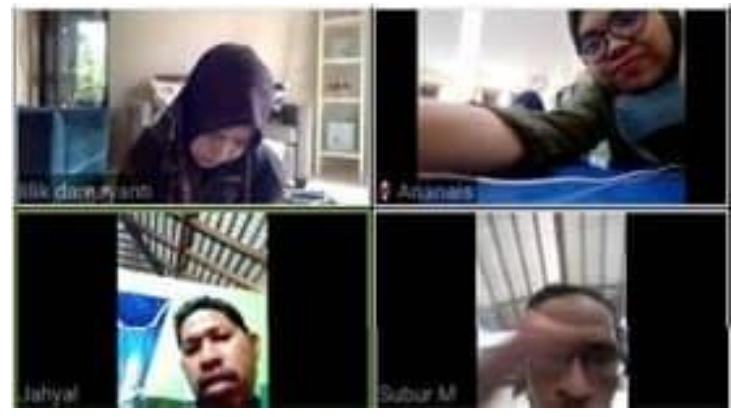

Figure 16. Online implementation of PkM DPRM 2020 on the third day.

Based on the results of filling out the online questionnaire, from the PkM participants, it can be seen that the very real outcomes felt by partners, especially those who work as fishermen and fried food seller, are related to the benefits of power plants without fuel, there are:

1. For the lighting of fishing boats, they no longer use a generator, so the operating cost of the generator which was 180 liters / month (IDR. 1.080,000), becomes IDR $0,-$ after using the tool.

2. For fried food seller who sell at night, their source of lighting no longer draws PLN electricity from surrounding houses. So that lighting at night can be fulfilled with the implementation of these tools. Even while selling fried foods, they can charge their cellphone when the battery drops. This means that savings in electricity costs from IDR 540,000 / month to IDR 0, -.

Table 1. Comparison of operational costs between generator use (requires fuel) by using a power plant without fuel

\begin{tabular}{cccc}
\hline No & Partner profession & Before & After \\
\hline 1 & Fishermen & IDR 1.080.000,- & IDR 0,-- \\
\hline 2 & Fried food seller & IDR 540.000,-- & IDR 0,-- \\
\hline
\end{tabular}


For important that the power source for this tool comes from a 12 volt $5 \mathrm{AH}$ battery for a 300 watt inverter capacity or a 12 volt $8 \mathrm{AH}$ battery for a 1000 watt inverter capacity. According to the narrative of 1 participant who works as a fry trader, the ability of a tool with a capacity of 300 watts is able to turn on 110 watt light point, 1 small fan and 1 cellphone charger simultaneously for 4 hours, even being able to last for 8 hours if you only turn on 1 light 10 watts. If the battery is worn out, it will take about 2 hours for the battery to be full. Meanwhile, a device with a capacity of 1000 watts is able to 2 lamps by 10 watt power, a water machine, and a refrigerator simultaneously for 2 hours. Based on this, the advantages of this tool for fishermen are presented in table 2.

Table 2. Comparison of operational costs between before and after for fisherman

\begin{tabular}{cllll}
\hline No & $\begin{array}{c}\text { Partner } \\
\text { condition }\end{array}$ & $\begin{array}{c}\text { Electricity cost } \\
\text { / month }\end{array}$ & \multicolumn{1}{c}{ Charger } & Electricity cost \\
\hline 1 & Before. & IDR 1.080.000,- & There is no & IDR 1.080.000,- \\
\hline 2 & After. & IDR 0,- & $\begin{array}{l}2 \text { hours / daily x 30 days } \\
=60 \text { hours / month }\end{array}$ & IDR 360.000,- \\
\hline
\end{tabular}

While the advantages of this tool for fried food seller are presented in table 3.

Table 3. Comparison of operational costs between before and after for fried food seller

\begin{tabular}{cllll}
\hline No & $\begin{array}{l}\text { Partner } \\
\text { condition }\end{array}$ & $\begin{array}{l}\text { Electricity cost } \\
\text { / month }\end{array}$ & Charger & Electricity cost \\
\hline 1 & Before. & IDR 540.000,- & There is no & IDR 540.000,- \\
\hline 2 & After. & IDR 0,- & $\begin{array}{l}2 \text { hours / daily x 15 days } \\
=30 \text { hours / month }\end{array}$ & IDR 180.000,- \\
& & &
\end{tabular}

Fried food seller can use this tool once charge for 2 days at night when selling.

Figure 17 and figure 18 below presents data on the comparison of the operational costs of lighting with a generator (fuel needed) with lighting by using a power plant without fuel. 


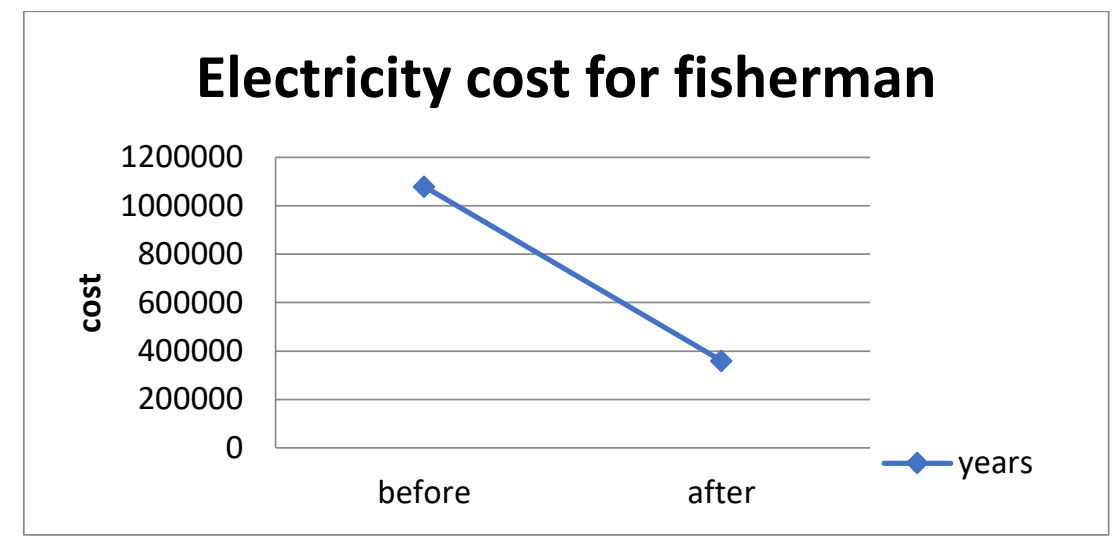

Figure 17. Graph of operating costs comparison of a generator set with a power plant without fuel for fisherman

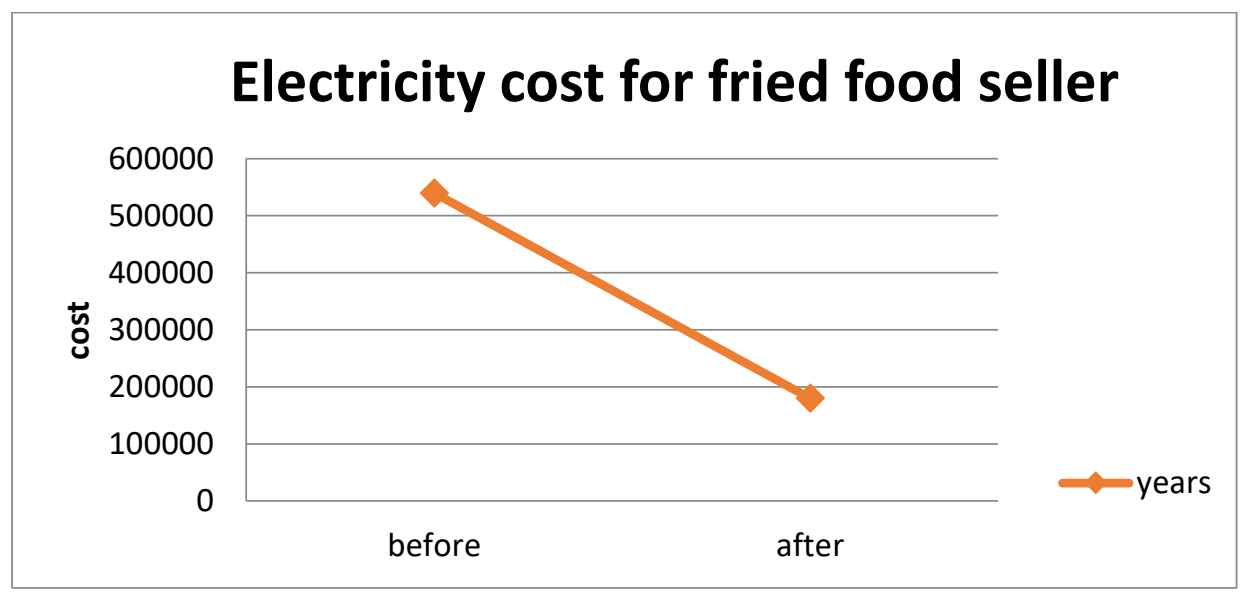

Figure 18. Graph of operating costs comparison of a generator set with a power plant without fuel for fried food seller

\section{CONCLUSIONS}

The PkM DRPM 2020 activity lasted for 3 days (2 days offline and 1 day online) running successfully and smoothly. Thanks to the excellent cooperation between the organizing team and the partners of Kelurahan Manggar. The enthusiasm of the fishermen and fried food seller in participating in this activity looks real. Fishermen and fried food seller have started to implement these tools in their daily activities. The offline activities ended with the signing of the minutes of handing over the tools between the PkM DRPM team and the partners represented by the Head of Kelurahan Manggar. There were 20 tools handed over, there are 19 units of tools with a capacity of 300 watts and 1 unit of tools with a capacity of 1000 watts, submitted on August 3, 2020, directly attended by all PkM DPRM participants. The power generator is an assembly between a 12 volt 5 Ah battery with a 300 watt inverter equipped with a 2 ampere battery charger (19 units) and a 12 volt 8 Ah battery with a 1000 watt inverter equipped with a 4 ampere battery charger (1 unit). This tool has proven to be energy saving according to the statement of the PkM participants who have implemented it as a source of lighting at night. 


\section{References}

Arota, A. S. (2013). Perancangan Sistem Pembangkit Listrik Hibrida (Energi Angin Dan Matahari) Menggunakan Hybrid Optimization Model For Electric. Jurnal MIPA Unstrat, 2(2), 145-150.

CNBC. (2018). Habis Pemilu, Harga BBM Bakal Naik Pertengahan Tahun 2019? Retrieved from CNBC Indonesia:

https://www.cnbcindonesia.com/news/20181130140255-4-44438/habis-pemiluharga-bbm-bakal-naik-pertengahan-tahun-2019

CNN. (2019, JUNI). Kelebihan Pasokan, Harga Minyak AS Merosot. Retrieved from https://finance.detik.com/energi/d-4577727/kelebihan-pasokan-harga-minyakas-merosot

hutagulung, S. N. (2017). PROTYPE RANGKAIAN INVERTER DC KE AC 900 WATT. Jurnal Pelita Informatika, 16(3), 278-280.

Juwito, A. F. (2012, Mei). Optimalisasi Energi Terbarukan pada Pembangkit Tenaga Listrik dalam Menghadapi Desa Mandiri Energi di Margajaya. Jurnal Ilmiah Semesta Teknika, 15(1), 22-34.

Mundus, R. (2010). RANCANG BANGUN INVERTER DENGAN MENGGUNAKAN SUMBER BATERAI DC12V.

Sinaga, Y. A. (2016). Rancang bangun inv dengan kontrolerter 1 phasa dengan kontrol pembangkit pulsa width modulation.

Wardhana, I. S. (2006). Perancangan inverter push pull resonan paralel pada aplikasi fotovoltaik.

Yani, A. (2018). RANCANG BANGUN PROTOTYPE PEMBANGKIT LISTRIK TENAGA UAP MINI SEBAGAI MEDIA PRAKTIKUM MAHASISWA . Jurnal Teknik Mesin Univ. Muhammadiyah Metro, 7(2). 


\section{Appendix}

\section{ONLINE QUESTIONNAIRE}

(https://docs.google.com/forms/d/1AiavgKMTttXMUPT6J165NOtFeWodzQNKMtUS1YVMq $\underline{\text { hc/edit) }}$
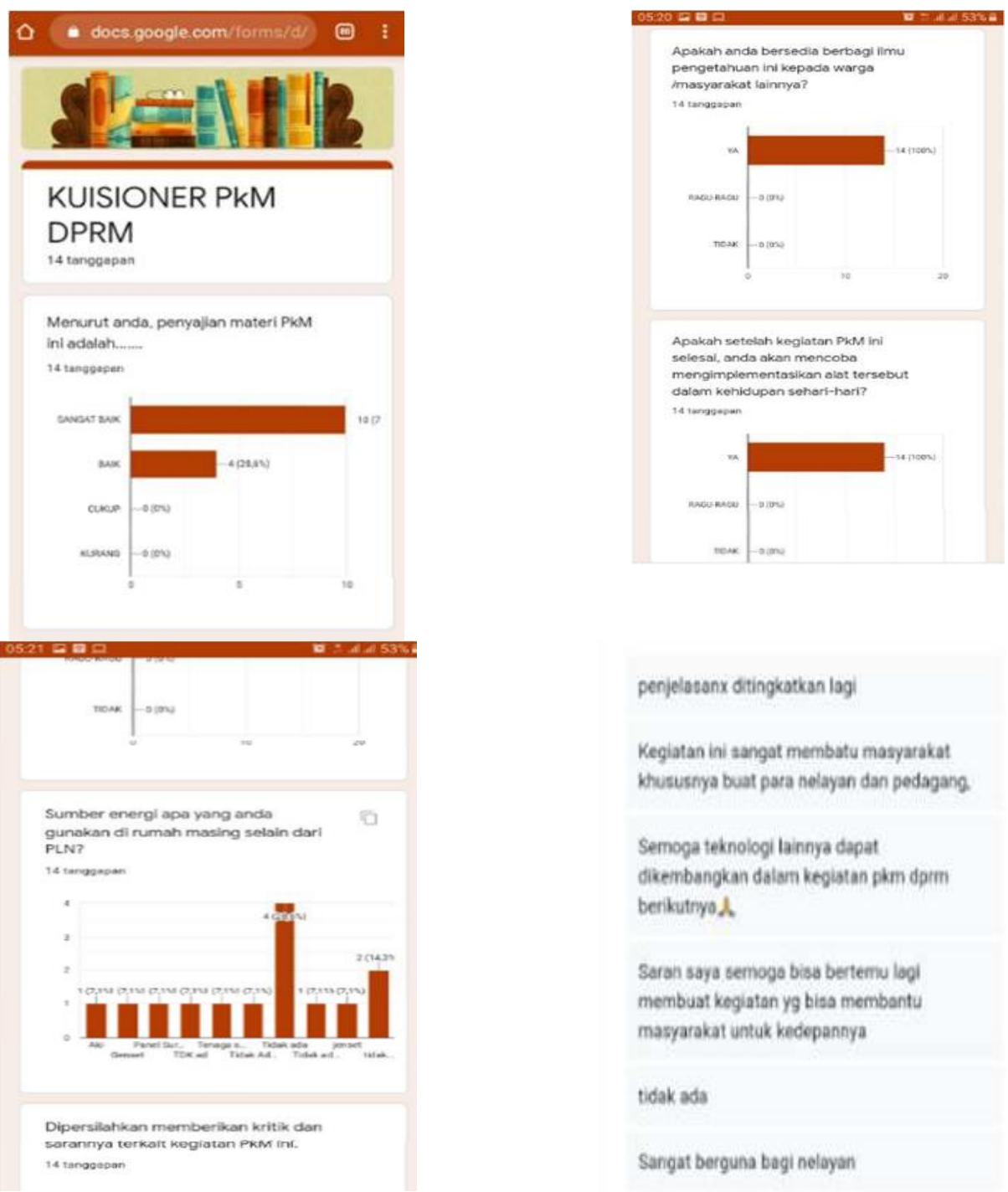

penjelosonx ditingkatkan lag

Kegiatan ini aangat membatu masyarakat Khususnya buat para nelayan dan pedagang.

Semoga teknologi lainnya dapat dikembangkan dalan kegiatan pim dpim berikutryo $\mathrm{A}$

Saran saya semoga bisa bertemu logi membuat kegiatan yg bisa membantu masyarakat untuk kedepannya

tidak ada

Sangat berguna bagi nelayan 
Indonesian Society of Applied Science

Journal of Applied Community Engagement

Vol. 01 No. 012021

e-ISSN 2808-7836

Saranrya: semoga ada logi seperti ini yang

sangat membantu para nelayan karena apabila

mati lampu ini sangat berguna. Untuck kritiknya

mungkin tidek ada

Maunya atotnya itu berikan ketika acaranya

Uda selesaikarna oda peserta yg tidak

hadir dan kagiatan seperti harus sering sering

diperkena kcan kemasyarakat agar menambath

limu politeknik

Sangat membantu sekail. Untuk sarannya.

mungkin sering2 untuk menyajkan seperti ini

Mudah mudahan apa yg kami pelajeri

bermantaat untuk karn

Snagat bak dan angt membantu untuk

pedagng kecil
Mudah mudahan apa yg kami petajari bermanfaat untuk kam

Snagat bak dan sngt membantu untuk pedagng kecil

Bogus

Timakasih dengan mahasiowo poitelbea, $y$ berhsrap kedepanx oda lagi bantuanz untuk masyankat menegah kebawah supaya bs laid mesyadi naik pelan 2 dan bs memajukan useha masing?

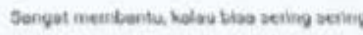
adakan aeperti in agat ita tidak terial banyak keluar dut 